Страшко Людмила Володимирівна аспірантка кафедри публічного управління та адміністрування Інституту підготовки кадрів державної служби зайнятості України, вул. Нововокзальна, 17, м. Київ, 03038, тел.: (044) 536-14-85, e-mail: strashkoludmila@ukr.net, https://orcid.org/0000-0002-3623-5077

\title{
МЕХАНІЗМИ ПУБЛІЧНОГО УПРАВЛІННЯ У СФЕРІ ЗАЙНЯТОСТІ НАСЕЛЕННЯ
}

Анотація. Стаття присвячена дослідженню публічного управління у сфері зайнятості та аналізу відповідних механізмів публічного управління у сфері зайнятості.

Встановлено, що публічне управління охоплює багато секторів та інститутів сучасного суспільства. Ефективний механізм публічного управління та адміністрування включає в себе всі загальні складники управлінського механізму: суб'єкт управління, наділений повноваженнями і обов'язками з управління; об'єкт управління, зобов'язаний реагувати на дії суб'єкта; суспільно значимий факт, що викликає необхідність публічного управління; спрямовані дії суб'єкта і дії об'єкта у відповідь на управління.

Проаналізовано, що сфера зайнятості населення та ринок праці є найбільш динамічними елементами економіки. В них не тільки переплітаються інтереси працівників i роботодавців, але й відображаються економічні, політичні, демографічні, соціальні та інші процеси. 3 активізацією процесів євроінтеграції відбулося перетворення національного ринку праці та державної служби зайнятості у напрямі набуття сервісно-орієнтованих характеристик та інноваційного типу розвитку.

3'ясовано, що одним із основних напрямів трансформації публічного управління в Україні є вдосконалення сфери надання публічних послуг у сфері зайнятості. Держава існує для виконання певних функцій - пропонувати громадянам соціальну допомогу, надавати публічні послуги. Охарактеризовано, що публічне управління - це пошук у найкращий спосіб використання ресурсів задля досягнення пріоритетних цілей державної політики. Поява нової форми управління у публічній сфері була спричинена потребою модернізувати організаційні структури і процедури, які вони використовують, для того, щоб усі інституції публічної сфери працювали краще. Публічне управління стосується ефективного функціонування всієї системи політичних інституцій. Державна 
політика зайнятості населення виконує своєрідну роль в узгодженні економічної та соціальної політики держави. 3 іiі допомогою детермінується ієрархія цілей та завдань регулювання пропорцій суспільного відтворення, забезпечується сприяння соціально-економічному розвитку суспільства.

Запропоновані наступні механізми публічного управління у сфері зайнятості: нормативно-правовий, інституційний, організаційно-економічний, інформаційний.

Ключові слова: держава, політика зайнятості, механізм, публічне управління, розвиток, сфера зайнятості.

Strashko Lyudmila Volodymyrivna Postgraduate student of the Department of Public Administration and Administration of the Institute for the Ukrainian state employment service training institute, Novovokzalna St., 17, Kyiv, 03038, tel.: (044) 536-14-85, e-mail: ribchinski@ gmail.com, https://orcid.org/0000-0002-3695-1903

\section{MECHANISMS OF PUBLIC ADMINISTRATION IN THE FIELD OF EMPLOYMENT OF THE POPULATION}

Abstract. The article is devoted to the study of public administration in the field of employment and analysis of the relevant mechanisms of public administration in the field of employment.

It has been established that public administration covers many sectors and institutes of modern society. The effective mechanism of public administration and administration includes all general components of the management mechanism: the management subject, endowed with powers and responsibilities for management; the object of management, is obliged to respond to the actions of the subject; a socially significant fact that causes the need for public administration; directed actions of the subject and action of the object in response to management.

It was analyze that the sphere of employment and labor market is the most dynamic elements of the economy. They were not only intertwine by the interests of employees and employers, but also reflected economic, political, demographic, social and other processes. With the intensification of European integration processes there was a transformation of the national labor market and the State Employment Service in the direction of acquiring service-oriented characteristics and innovative development type.

It has been found that one of the main directions of transformation of public administration in Ukraine is to improve the sphere of public employment services. The state exists to carry out certain functions - to offer social assistance to citizens, provide public services. Described that public administration is a search for the best way to use 
resources to achieve priority objectives of public policy. The emergence of a new form of management in the public sphere was caused by the need to modernize the organizational structures and procedures that they use, so that all public sphere institutions work better. Public administration relates to the effective functioning of the entire system of political institutions. The state policy of employment of the population performs a peculiar role in coordinating the state's economic and social policy. With its help, the hierarchy of goals and tasks of regulation of proportions of social reproduction are determined, promoting socio-economic development of society.

The following mechanisms of public administration in the field of employment were propose: normative legal, institutional, organizational and economic, informational.

Keywords: State, Employment Policy, Mechanism, Public Administration, Development, Employment.

Постановка проблеми. Трансформація сфери надання публічних послуг населенню є одним з пріоритетних завдань модернізації публічного управління в Україні. Реалії сьогодення засвідчують появу нових суб’єктів, які реалізують власні інтереси, змінюються інститути (створюються нові структури) та інституції (впроваджуються нові стратегії, закони). Відповідно відбувається i зміна механізмів та інструментів публічного управління.

Аналіз останніх досліджень і публікацій. Дану тему досліджувало багато національних та зарубіжних науковців i практиків, зокрема, Л. Малюга [2], О. Загороднюк [2], А. Медведь [2] вивчали механізму публічного управління та адміністрування, підвищення якості послуг у сервісно-орієнтованій моделі держави тощо. Дослідженню інших аспектів ринку праці та зайнятості присвячено праці вітчизняних науковців: В.Близнюк, О.Грішнової, О. Коломійця, А. Колота, І. Петрова, В. Петюха та інших. Вивченню теоретичних та практичних аспектів інституціональних перетворень ринку праці, системи соціального забезпечення, формування та реалізації державної політики у сфері зайнятості населення в Україні присвячено наукові дослідження С. Архієреєва, А. Гриценка, П. Мазурка, Ю. Маршавіна, О. Петроє, Н. Савченко, О.Сардака, В. Сибірцева [7] та ін.

Метою статті $є$ дослідження публічного управління у сфері зайнятості та аналіз відповідних механізмів публічного управління у сфері зайнятості.

Виклад основного матеріалу. Термін «публічне управління» характеризує внутрішню діяльність державних установ, зокрема вирішення таких управлінських питань, як контроль, керівництво, планування, організаційне забезпечення, забезпечення інформаційними технологіями, управління персоналом та оцінка ефективності [1]. Публічне управління охоплює багато 
секторів та інститутів сучасного суспільства. Ефективний механізм публічного управління та адміністрування включає в себе всі загальні складники управлінського механізму: суб’єкт управління, наділений повноваженнями i обов'язками 3 управління; об'єкт управління, зобов'язаний реагувати на дії суб'єкта; суспільно значимий факт, що викликає необхідність публічного управління; спрямовані дії суб'єкта і дії об'єкта у відповідь на управління [2].

Одним із основних напрямів трансформації публічного управління в Україні $\epsilon$ вдосконалення сфери надання публічних послуг у сфері зайнятості. Держава існує для виконання певних функцій - пропонувати громадянам соціальну допомогу, надавати публічні послуги. Держава не управляє громадянами, а надає їм послуги. Її різноманітні дії спрямовані на створення умов для реалізації громадянами своїх прав та свобод. Відповідно до цього новими рисами загального стилю державного управління стали чутливість до конкретних потреб громадян у послугах, тобто орієнтація на їх виявлення і задоволення, забезпечення зручності надання послуг для громадян, мінімізація витрат часу та ресурсів [3].

10 березня 2021 року на засіданні Уряду прийнято постанову щодо удосконалення механізмів надання послуг населенню Державною службою зайнятості України. Зокрема, документом передбачено такі зміни:

- підтвердження безробітним наміру перебувати в статусі безробітного в період карантину в дистанційному режимі без необхідності безпосереднього відвідування центру зайнятості;

- збільшення 310 до 30 днів строку подання до центрів зайнятості документів, на підставі яких їм було надано статус в період карантину в режимі онлайн;

- впровадження дистанційного складання плану працевлаштування;

- отримання права на проходження професійної підготовки особами, звільненими з військової служби після участі у проведенні АТО до досягнення ними пенсійного віку;

- поширення права на отримання роботодавцями компенсації за сплату ССВ за працевлаштування непрацюючих працездатних осіб, які отримують державну соціальну допомогу малозабезпеченим сім'ям.

Соціолог Мері Паркер Фоллетт запропонувала дефініцію категорії «управління» (англ. - management) як «мистецтво виконувати роботу через інших людей» [4]. Це визначення вказує на те, що підвищити дієвість управління можна шляхом підвищення ефективності використання людських ресурсів. Відповідно до неокласичної теорії менеджменту у центрі уваги перебуває людина, а не організаційна структура. Так, у державному секторі модель публічного адміністрування («бюрократична модель») трансформувалася у модель публічного управління («ринкова модель»): акценти змістилися 3 виконання 
роботи згідно з інструкціями та чіткими правилами на роботу, що спрямована на надання якісних публічних послуг та досягнення ефективних результатів. Незважаючи на те, що управління у приватній та публічній сферах почало здійснюватися подібно, публічне управління має свої особливості. Головна мета будь-якого управлінця у публічній чи у приватній сфері - 3 мінімальними витратами ресурсів, часу і зусиль досягнути максимальної ефективності, дієвості i результативності. Основне ж завдання, яке стоїть перед публічним управлінцем, відмінне від завдання, яке виконує бізнес-управлінець. Якщо бізнесовий управлінець своєю діяльністю прямо впливає на отримання прибутку певної підприємницької одиниці, то публічний управлінець - на якість життя громадян певної адміністративно-територіальної одиниці чи держави в цілому. Публічний управлінець намагається найбільш раціонально використати наявну інфраструктуру для надання публічних благ та задоволення суспільного інтересу.

«Публічне управління» - це пошук у найкращий спосіб використання ресурсів задля досягнення пріоритетних цілей державної політики [5]. Поява нової форми управління у публічній сфері була спричинена потребою модернізувати організаційні структури і процедури, які вони використовують, для того, щоб усі інституції публічної сфери працювали краще. Публічне управління стосується ефективного функціонування всієї системи політичних інституцій. Отже, є певні механізми, за якими формується та реалізується політика зайнятості. 3 огляду на це наведемо механізми публічного управління у сфері зайнятості:

1. Нормативно-правовий механізм - це ієрархічний комплекс правових норм та принципів, які врегульовують зміст та процес здійснення політики зайнятості, тобто правовий механізм сфери зайнятості, та комплекс ролей та взаємозв’язків, що містить правовідносини, які утворюються під час проведення політики зайнятості та низку специфічних ролей, форм i методів роботи суб'єктів здійснення цієї політики. Насамперед, це Конвенції Міжнародної організації праці, Цілі Сталого Розвитку до 2030 р., Пріоритети Східного Партнерства до 2020 р., Угода про асоціацію між Україною та СС. Останнім документом, глава 21 «Співробітництво у галузі зайнятості, соціальної політики та рівних можливостей», передбачено необхідність «посилення діалогу та співробітництва щодо забезпечення гідної праці, політики зайнятості, безпечних та здорових умов праці, соціального діалогу, соціального захисту, соціального залучення, гендерної рівності та недискримінації» 3 метою: розв'язання проблем глобалізації, демографічних змін; зменшення тіньової економіки; забезпечення збільшення кількості робочих місць 3 гідними умовами праці; модернізація системи соціального захисту; просування соціального діалогу та ін. Закони України: «Про зайнятість населення» від 5 липня 2012 року № 5067-VI., «Про 
загальнообов'язкове державне соціальне страхування» від 2 березня 2000 року № 1533-III. Генеральна угода про регулювання основних принципів і норм реалізації соціально-економічної політики і трудових відносин в Україні на 2019-2021 роки від 14 травня 2019 року та інші нормативно-правові акти (накази, постанови, розпорядження).

2. Інституційним механізмом є комплекс державних інститутів, що задіяні, під час того, як формується і впроваджується політика зайнятості. На думку Д. Норта основу інституційного середовища утворює певна норма або стандарт поведінки, яка визнана у суспільстві. Такі соціальні норми та їх угрупування мають місце в кожній зі сфер суспільних відносин, а інституційний розвиток пов'язаний із взаємодією інтересів, стимулів та правил [6]. Їх унормування може бути визначено у формальних або неформальних інституціях: кодексах, законах та інших нормативно-правових актах або суспільних звичаях. Аналіз інституційної складової для забезпечення збалансованості на ринку праці на основі системного підходу присвячено дослідження В. Сибірцева. Науковець визначив стратегічні орієнтири, яких планується досягти у разі забезпечення збалансованості ринку праці. В запропонованій моделі сформовано структурну взаємодію та напрями впливів інститутів ринку праці за зовнішніми та внутрішніми рівнями збалансованості [7].

Особливе місце у сфері регулювання праці та зайнятості населення займає МОП, діяльність якої побудовано на засадах трипартизму (тристороннє представництво органів державної влади, профспілок та організацій роботодавців) та соціального діалогу. Конвенції та рекомендації МОП спрямовані на вироблення узгоджених рішень представниками працівників, роботодавців, влади та $є$ обов'язковими для керівництва в роботі державами-учасницями [8]. Національну систему зайнятості побудовано 3 урахуванням міжнародних підходів.

Відповідно до рекомендацій МОП функції з реалізації державної політики у сфері зайнятості населення задля забезпечення повної зайнятості та розвитку продуктивних сил покладаються на національну службу зайнятості та їі мережу. Головне завдання діяльності полягає в забезпеченні ефективного добору та влаштування працівників на роботу [9]. Державна служба зайнятості України, створена у 1990 році, реалізує державну політику у сфері зайнятості населення. Їі діяльність регламентується Законами України «Про зайнятість населення», «Про загальнообов'язкове державне соціальне страхування на випадок безробіття», Положенням про державну службу зайнятості та ін. Головною державною установою у системі державної служби зайнятості є Державний центр зайнятості, який виконує повноваження безпосередньо через регіональні та базові центри зайнятості, їхні філії, навчальні заклади Служби та підпорядкованих Службі 
юридичних осіб. Таким чином, центральний апарат Служби визначає функції та обсяг повноважень регіональних і базових центрів зайнятості, а також їхніх філій [10].

3. Організаційно-економічний механізм - сукупність важелів та інструментів забезпечення сфери зайнятості України, серед яких основними є прогнозування, регулювання та управління процесами зайнятості. При цьому необхідним $\epsilon$ забезпечення науково обгрунтованого прогнозування різних аспектів розвитку професійного ринку праці; створення сучасної інформаційної бази, що передбачає використання балансових методів, а також застосування світового досвіду функціонування систем територіального соціально-економічного моніторингу; заходи з регулювання пропозиції робочої сили та іiі наближення до структури попиту на неї за професіями, а також заходи з розширення попиту на робочу силу; розробка і реалізація ефективних програм сприяння зайнятості населення на державному, регіональному і місцевому рівнях [11].

4. Інформаційний механізм грунтується на тому, що кожний суб'єкт інформаційного процесу повинен мати відповідну правову свідомість, бути законослухняним, добре уявляти наслідки свої дій для інших суб'єктів та міру відповідальності на випадок порушення їхніх життєво важливих інтересів. Нові форми i види зайнятості $\epsilon$ реакцією на виклики сучасності i потребують законодавчо-економічного реагування зі сторони державних інституцій. Здійснюючи заходи в сприянні працевлаштування, служба зайнятості співпрацює з підприємствами, установами, організаціями та надає послуги різним категоріям громадян. Технології взаємодії змінюються - впроваджуються інформаційні технології, індивідуалізація надання послуг та розширення каналів комунікації - i тому потребують осмислення та впровадження нових ресурсних можливостей [12].

Наразі функціонує оновлений сайт державної служби зайнятості України, який містить: інформацію щодо структури та управління в сфери зайнятості; інформаційні блоки про перелік та умови отримання послуг «Громадянам», «Роботодавцям», «Аналітика та статистика» та ін.; електронні сервіси «Електронна черга», «Електронний кабінет шукача роботи», «Електронний кабінет роботодавця»; інтегровані вебпортали пошуку вакансій та регіональних служб зайнятості; освітній портал (https://skills.dcz.gov.ua/), на якому розміщено інформаційні та навчальні ресурси для громадян, роботодавців та працівників служби та ін.

Ці сервіси надають можливість дистанційно в зручний час ознайомитись 3 переліком і порядком отримання послуг, що надаються службою зайнятості: самостійного онлайн пошуку роботи і добору працівників, у тому числі допомогу у створенні та поширенні відео резюме, підготовку та проведення онлайн 
співбесід шукачів роботи з роботодавцями, відкриття власної справи, отримання нової професії та підвищення кваліфікації та ін.

Висновки. Узагальнюючи, можливо зробити висновок, що в Україні на державному рівні сформовано цілісну систему управління сферою зайнятості, яка відповідає міжнародним умовам регулювання сфери зайнятості. Ефективна взаємодія державних інституцій та органів місцевого самоврядування, профспілкових і громадських об'єднань, що відстоюють інтереси працюючих, роботодавців, закладів освіти як на національному, так i на регіональному $\mathrm{i}$ місцевих рівнях забезпечує реалізацію конституційних прав громадян у сфері праці та зайнятості. Це передбачає визначення переліків відповідних заходів, форм та методів їх реалізації, своєчасний аналіз та ефективність їх застосування тощо, а також системність проведення відповідних реформ з огляду на вимоги часу.

\section{Лimepamypa:}

1. Глосарій Програми розвитку ОOH. URL: http://www.unpan.org/Directories/ UNPublicAdministrationGlossary

2. Малюга Л. М., Загороднюк О. В. Формування механізму публічного управління та адміністрування в Україні. Східна Європа: економіка, бізнес та управління, Випуск 3 (03), 2016. C. $62-65$.

3. Медведь А. В. Підвищення якості послуг у сервісно-орієнтованій моделі держави. Державне управління: теорія та практика №1, 2019. С. 50-57.

4. Mary P. Follett. Creating Democracy, Transforming Management, Tonn, Joan C., New Haven: Yale University Press, 2003. 366 p.

5. Keeling D. Management in Government, 1972. London: Allen \& Unwin.

6. Davis, Lance E and Douglass C North (1971), Institutional Change and American Economic Growth, Cambridge, UK: Cambridge University Press.

7. Сибірцев В. В. Розвиток інституціональної складової державного регулювання збалансованості національного ринку праці. Економіка розвитку. 2017. № 1. С. 39-49.

8. Загальна декларація прав людини : прийнята і проголошена резолюцією 217 А (III) Генеральної Асамблеї ООН від 10 груд. 1948 p. URL: https://zakon.rada.gov.ua/laws/show/ 995_015\#Text

9. Конвенція Міжнародної організації праці № 88 про організацію служби зайнятості URL: https://zakon.rada.gov.ua/laws/show/993_224\#Text

10. Положення про державну службу зайнятості, затверджене наказом Міністерства соціальної політики України від 14.06.2019 року № 945, зареєстровано в Міністерстві юстиції України від 04.07.2019 p. за № 733/33704. URL: https://zakon.rada.gov.ua/laws/show/z0733-19\#Text

11. Добренко О.Напрями удосконалення організаційно-економічного механізму державного регулювання професійного ринку праџуі. Україна: аспекти праці. 2014. № 7. С. 44 49. URL: http://nbuv.gov.ua/UJRN/Uap_2014_7_9

12. Співпраця служби зайнятості 3 сайтами пошуку роботи, приватними агентствами зайнятості, галузевими об'єднаннями роботодавців та іншими представниками бізнесу 3 
урахуванням міжнародних практик: науково-практичні рекомендації / за заг. ред. Войтович Р.В. та Линдюк О. А. Київ: ІПК ДСЗУ, 2020. 60 с.

\section{References:}

1. Glosarij Programy` rozvy`tku OON [Glossary United Nations Development Program]. URL: http://www.unpan.org/ Directories/UNPublicAdministrationGlossary [in Ukrainian].

2. Malyuga, L. M., Zagorodnyuk, O. V. (2016). Formuvannya mexanizmu publichnogo upravlinnya ta administruvannya $\mathrm{v}$ Ukrayini [Formation of a mechanism for public administration and administration in Ukraine]. Sxidna Yevropa: ekonomika, biznes ta upravlinnya - Eastern Europe: Economics, Business and Management, 3 (03), 62-65 [in Ukrainian].

3. Medved', A. V. (2019). Pidvy`shhennya yakosti poslug u servisno-oriyentovanij modeli derzhavy` [Improving the quality of services in a service-oriented model of the state]. Derzhavne upravlinnya: teoriya ta prakty`ka - Public Administration: Theory and Practice 1, 50-57 [in Ukrainian].

4. Mary, P. Follett (2003). Creating Democracy, Transforming Management, Tonn, Joan C., New Haven: Yale University Press, 366 p [in English].

5. Keeling, D. (1972). Management in Government. London: Allen \& Unwin [in English].

6. Davis, Lance E and Douglass C North (1971), Institutional Change and American Economic Growth, Cambridge, UK: Cambridge University Press [in English].

7. Sy`bircev, V. V. (2017). Rozvy`tok insty`tucional’noyi skladovoyi derzhavnogo regulyuvannya zbalansovanosti nacional'nogo ry`nku praci [Development of institutional component of state regulation of balancing of the national labor market]. Ekonomika rozvy $t k u-D e v e l o p m e n t$ economy, 1, 39-49 [in Ukrainian].

8. The general declaration of human rights: adopted and proclaimed by resolution $217 \mathrm{~A}$ (III) UN General Assembly of 10.12.1948. URL: https://zakon.rada.gov.ua/laws/show/995_015\#Text [in Ukrainian].

9. Konvenciya Mizhnarodnoyi organizaciyi praci №88 pro organizaciyu sluzhby` zajnyatosti [Convention of the International Labor Organization №88 on the organization of employment service] URL: https://zakon.rada.gov.ua/laws/show/993_224\#Text [in Ukrainian].

10. Polozhennya pro derzhavnu sluzhbu zajnyatosti, zatverdzhene nakazom Ministerstva social 'noyi polity`ky` Ukrayiny` [Regulations on the State Employment Service approved by the Order of the Ministry of Social Policy of Ukraine] 14.06.2019, № 945. URL: https://zakon.rada.gov.ua/laws/show/z0733-19\#Text [in Ukrainian].

11. Dobrenko, O. (2014). Napryamy udoskonalennya organizacijno-ekonomichnogo mexanizmu derzhavnogo regulyuvannya profesijnogo ry`nku praci [Directions of improvement of the organizational and economic mechanism of state regulation of the professional labor market]. Ukraine: aspects of labor -Ukraine: aspects of labor, 7, 44-49. URL: http://nbuv.gov.ua/UJRN/Uap_2014_7_9 [in Ukrainian].

12. Spivpracya sluzhby`zajnyatosti z sajtamy` poshuku roboty`, pry`vatny`my`agentstvamy zajnyatosti, galuzevy`my` ob'yednannyamy` robotodavciv ta inshy`my` predstavny`kamy` biznesu z uraxuvannyam mizhnarodny`x prakty`k: naukovo-prakty`chni rekomendaciyi [Cooperation of employment services with job search sites, private employment agencies, industry associations of employers and other business associations, taking into account international practices: scientific and practical recommendations], Kyiv, Ukraine [in Ukrainian]. 